\title{
Present Situation and Reform Ideas of Computer Training Base Construction
}

\author{
Shuyao Zhuo, Fengxian Deng \\ (Hainan college of software technology, hainan,qionghai,571400)
}

Keywords: Computer; Training base construction; Status quo; Reform

\begin{abstract}
Computer training base construction is of great importance to the cultivation of applied talents in colleges and universities. Aiming at our university talents one-sided training, reform training base construction is put forward, and in the process of teaching, pay attention to the cultivation of students' vocational ability. Training base construction takes serve the society as the goal, employment as the guidance, practice ability as the basis to promote the development of computer professional education in higher vocational colleges, improve students' computer application ability, and lay a solid foundation for getting into society in order to better serve the society. This article mainly analyzes the current situation of the construction of computer training base in higher vocational colleges in our country and further reform measures.

With the development of science and technology, electronic information industry develops rapidly, especially the development of computer changes the original way of work and communication. Computer is an important symbol of new technology revolution. In this environment, education in colleges and universities must focus on modernization, pay attention to the cultivation of computer professionals, and provide professional quality of computer talents for the society. But our university computer teaching prevalent problems are theory-emphasized, practice-lighted, which are unfavorable to the cultivation of talents. Based on this, colleges and universities should strengthen computer training base construction to improve students' practice ability and develop high technology applied talents.
\end{abstract}

\section{The significance of building up training base in higher vocational colleges}

In recent years, information technology has developed rapidly, so the society needs a large number of computer professional talents. Colleges and universities need to cultivate specialized talents, especially higher vocational colleges, which main cultivation is production and construction of specialized talents with professional skills and professional quality. Main characteristics of this kind of school are to cultivate applied talents, and pays attention to training students' practical operation ability. Computer training base construction is the most effective way to train students' professional ability. Training base is the basis of practice teaching platform, and is students practice class's main venue.

Computer training base construction is the basic way of training skilled talents in higher vocational colleges. Colleges and universities improve students' practical skills through computer training base construction, make the students form a good professional habit, and improve students' professional quality. So the stand or fall of university computer training base construction is directly related to the training teaching effect, which directly affects personnel skill levels and quality at the same time, also affects society conveying ability level, so colleges and universities should put special emphasis on computer practice base construction, and improve the level of computer professional training talents in colleges and universities.

The main purpose of computer training base construction is to help course complete computer personnel training target, provide computer practice teaching base, provide students with practical skills training, let the student feel in advance enterprise working environment, work mode, basic content and so on, and improve students' professional quality. It also realizes the education mode of perfect combination of computer theoretical knowledge and practical skills, and completes 
computer teaching target. Computer training course in higher vocational colleges, through the research of curriculum, relevant skills assessment, project development and technical services, undertakes the task of computer vocational skills training. In the true sense, it improves students' practice ability and application ability. Under the continuous improvement of computer training base, it will gradually become an integrated teaching base of computer vocational skills training, evaluation, project research and development, which can effectively promote the improvement of students' professional skills.

\section{Higher vocational college computer construction situation and existing problems of training bases}

At present, vocational colleges generally offer training teaching base, actively respond to training teaching reform, build perfect practice teaching system, realize real training, and turn practicing training teaching reform towards comprehensive teaching in our country. But inevitably there are some problems in the process of development, such as many colleges and universities on the productive practice are still in groping stage, and have not form a system theory, also do not have complete control over how to perform the organic union between college productive training base and practice quarter, and is not conducive to the development of training base.

A. Computer training base construction has less investment and is of low level

At present, higher vocational college's campus computer training base construction work is in the stage of development. Leadership need to attach great importance to it and give enough financial support, but in the process of training teaching construction in colleges and universities, investment in practice training bases is seriously insufficient with less money, which leads to inadequate school improvement and new training base conditions, and do not have enough money to buy the necessary equipment. Much college training base adopts way of practice, which does not implement the practice in real situation; college training base construction level is lower. There is a big difference in the scale of computer major in higher vocational colleges which needs production bases of campus, and is insufficient to implement efficient computer reform goals of the construction of practice training bases.

B. School-enterprise supply mechanism is not sound in colleges and universities

The cultivation of computer major in higher vocational colleges is mainly applied talents, and the main goal is to cultivate professional computer talents for the society, which pays attention to the cultivation of students' practical ability. And university-enterprise cooperation in running schools can achieve this goal very well; university-enterprise co-building school production bases introduce the most real technical service, let the student feel in advance enterprise working environment, so that the students can quickly adapt to work after entering society, and realize their own value. But the cooperation of enterprises in colleges and universities generally has problems, such as small enterprise scale, less volume, and less service project, so school can organize students for less real productive activities, and practice time more restricted compared to commonly practice, which is unfavorable to the improvement of students' practical ability. In addition, the introduction of cooperative enterprises provides students with relatively less internship, and the directions of professional development and school do not very match. Enterprises with direct construction of practice base are less, so school organizations of students practice are often restricted to facilities, equipment, strict product process specifications, time limit for a project, such as raw materials, not very good implementation practices, so this kind of situation often leads to school-active with rarely active companies' cooperation, so it is difficult to form effective win-win cooperation mode between higher vocational colleges and enterprises. The main reason of the phenomenon is that enterprise rarely sees the superiority of this mode and benefit development in a relatively short period of time, and they just one-sided think students experiment is insufficient. With more complex things, it is difficult to control and affects the working process and so on, and this leads to low cooperation enthusiasm.

C. Computer training base construction is lack of a unified management system

At present, the computer training base in higher vocational colleges has still not formed a mature 
management system, and there are many problems in the construction of practice training bases. It cannot promote and guarantee students on campus for the effect of practical training management mechanism, and students tend to be loose in the process of training practice and lack of constraints, causing students carrying on practice training and outdoor sports lessons. In addition, there is no reasonable training course examination system. Students' evaluation is still like traditional pure theory examination, so it is difficult to achieve a comprehensive and effective understanding of students' learning situation. In addition, university-enterprise cooperation becomes a mere formality, and work-integrated learning development models are not mature enough, which did not make full use of campus practice base construction and lost major significance of the real role of practical base construction. Many higher vocational colleges are in a cluttered laboratory management system, such as experimental teaching belongs to educational administration; construction of laboratory team belongs to personnel office; laboratory construction belongs to lab and equipment administration management. Lack of unified management causes the occurrence of repeated construction, causing huge waste of money, resources, manpower. Laboratory team construction and management are not perfect; personnel structure is unreasonable, and there is no complete evaluation mechanism, which to a certain extent restricts the cultivation of innovative talents.

D. Teachers strength needs to be improved

In higher vocational colleges at present, many teachers are generally computer professional students directly graduated from schools. They have no teaching experience; they don't have a line for students' management; courseware is not very familiar and lack of practical experience. Plus schools' heavy teaching task, not only bear the theory class teaching, and bear the practical lesson, the research of construction and other teaching tasks. It is difficult to put more time into the construction of practice training rooms, and teachers cannot timely solve the problems of students in training room, which reduces the enthusiasm of students' learning. It is difficult to conduct a comprehensive, systematic and true illustration for students.

\section{Computer training base construction reform measures}

Vocational college computer professional training base construction should be able to integrate school resources, establish a comprehensive, high quality and systemic training base, promote the interaction between the personnel, the situation of resource sharing, information exchange, combined with a set of scientific and reasonable training base management system, and realize teaching practicality and openness as well as professionalism. Practice teaching has become an important part of higher vocational teaching, but also the necessary places to develop the innovative ability of students' practice. Training room construction, therefore, directly affects the level of teaching in higher vocational colleges, so in the process of construction, solve the existing problems in time to ensure that the training room works effectively.

A. Increase funding for construction of practice base and establish a diversified funds safeguard system

Aimed at training room problems such as outdated equipment, lack of space, and money shortages, schools should increase capital input to training room construction, and construct special funds to build training rooms. This sector funds cannot divert at liberty and must be used for the related training room construction and all kinds of complete equipment and facilities: update equipment, materials, and security training rooms. In addition, the school can fully cooperate with enterprise, takes advantage of the school and students' skill of specialty, and partnership enterprise practices, at the same time make enterprises funded research and development spending and training rooms cost to achieve a win-win situation. Schools can also establish alumni fund at the same time, and actively guide and encourage some achievements of alumni contribution for the school to carry out the training room construction.

B. Strengthen the construction of double qualified faculty

Teacher is the mentor of student knowledge. For higher vocational colleges, to cultivate students of higher technical ability, excellent teaching staff must have comprehensive abilities. Higher vocational teachers should not only consider the teacher's education and qualifications, but also pay 
attention to improve teachers' practical ability and professional skills, encourage teachers to go deep into the first line enterprise production, participate in the activities of the enterprise, including product manufacturing, production management, product development, technical innovation, equipment maintenance, product sales, etc., make the teacher's practice ability get greatly increased; At all levels encourage teachers to guide students to attend all kinds of professional skills contests, be a technical supervisor eugenics and comprehensively promote the double quality of teachers.

School can hire companies' outstanding software developers for school part-time computer practice teaching to build enterprise cooperation school training base for software and hardware construction. University-enterprise cooperation with Qingdao software park, for example, selected 5 years experience engineers in project development into campus Jin Fuxing for a period of six months or 3 months training teaching, guided students in accordance with the requirements for enterprise project, completed specifications of programming, testing, and writing, etc, at the same time several teachers participated in the teaching, learning experience; In addition sent professional teachers to guide enterprise research and development department, research and development and learning, this can not only increase the school teachers' enterprise practice experience, but promote the two sides to achieve win-win situation and raise the level of school training base construction.

C. Construction of the real practical training environment and improve the management level

The practice teaching management of higher vocational colleges can't be a single management mode, and should be combined with a variety of management manners, which can use the combination of centralized and decentralized management modes. Centralized management is mainly used for teaching equipment, and sites need unified management aspects, and decentralized management is applied in practice teaching, which is because the number of students is more general, and unified management has certain difficulty, so we can adopt decentralized management. In colleges and universities, set up a number of different professions, each student has the corresponding personnel and department of management. Such teaching regulation is clearer and can effectively guarantee the improvement of teaching quality.

University computer training base construction has to achieve practical environment simulation enterprise real working environment. In laboratory practice base construction, develop software training room, network interconnection room, plane design training rooms, training rooms bay station construction, and informatization office training rooms, such as the real simulation of enterprise working environment, enterprise management system is introduced into the classroom. Let the student drill 8 hours a day with the identity of enterprise staff training process, pay attention to the role transformation in practice, teachers can be converted into enterprise managers, and in accordance with the enterprise management system, carry out check on work attendance, training $\log$ to fill in, etc., and comprehensively improve students' practical ability.

\section{Conclusion}

In a word, computer training base construction is a necessary form conforming to quality education in higher vocational colleges, which is also a necessary way of cultivating professional talents in colleges and universities. To solve the problems existing in the construction of training base in time, pay attention to each link of the process of practical training teaching management, improve training construction management work, carry out the practice teaching in a variety of ways, enrich the students' training courses, improve students' practice ability, innovation ability and professional skills, and cultivate development-oriented, and innovative technology skills talents a large number of industrial transformation, upgrading and enterprise technology innovation needs.

\section{References}

[1] Guo Jianhui. Higher vocational training base construction reform research [J]. Computer Education, 2010, (17) : 143-145. 
[2] Lv Alu, Liu Xixun. On teaching reform of higher vocational computer software profession [J]. Journal of Vocational Education BBS, 2005, (20) : 13-14.

[3] Wang Anna. Introduction to the role of secondary vocational computer skills competition for teaching reform [J]. China's New Technology and New products, 2011 (17) : 234-234.

[4] Xu Dahong. Five-year higher vocational computer application technology professional personnel training mode exploration [J]. Journal of Vocational Education, 2012, (17) : 21-23.

[5] Zhao Yunpeng. Higher vocational computer school training base construction and ability of the students' employment research [J]. Journal of Electronic Commerce in China, 2012, (24) : 129-130.

[6] Shi Yihe. Research and exploration of higher vocational computer professional practice teaching [J]. China's School Education (Theory), 2011, (3): 168.

[7] Li Renpu. Computer science and technology applied talents training reform research analysis Take eastern university for example [J]. Journal of Computer Education, 2012, (15) : 43-48. 